\section{The European Union's Reaction to the Venezuelan Migration Crisis}

\author{
La reacción de la Unión Europea \\ a la crisis migratoria venezolana
}

\author{
Maria Ochab* \\ FACULTY OF POLITICAL SCIENCE AND JOURNALISM \\ MARIA CURIE-SKŁODOWSKA UNIVERSITY \\ LUBLIN, POLAND \\ $\triangle$ maria.ochab@umcs.edu.pl \\ https://orcid.org/0000-0002-0061-3558
}

Anuario Latinoamericano Ciencias Políticas

y Relaciones Internacionales

vol. 9, 2020

pp. $113-134$

DOI: 10.17951/al.2020.9.113-134

\begin{abstract}
The main objective of this article is to analyze the actions undertaken by the European Union (EU) as a reaction to the political and economic crisis which has led to a massive exodus of Venezuelan citizens in recent years (since 2015), and in particular after the last presidential elections. The article will outline current critical situation in Venezuela, first by presenting the political background and then by describing the general picture of the Venezuelan economy and hardships that resulted in this unprecedented migratory movement. Building on the hypothesis that being a global player is in keeping with the aspirations of the EU, the second part of the article analyzes both political and financial measures undertaken by various European institutions to help mitigate this humanitarian crisis.
\end{abstract}

KEYWORDS: migration crisis, political crisis, Maduro's regime, European Union, Venezuela.

\section{RESUMEN}

El objetivo principal de este artículo es analizar las acciones emprendidas por la Unión Europea (UE) como una reacción a la crisis política y económica que ha causado un éxodo masivo de ciudadanos venezolanos en los últimos años (desde 2015) y, en particular, tras las últimas elecciones presidenciales. La situación crítica actual en Venezuela se describirá, primero, presentando los antecedentes políticos y luego describiendo el panorama general de la economía venezolana y las dificultades que llevaron a este

* Master's Degree in Iberian Philology from Maria Curie-Skłodowska University, Lublin, Poland. PhD course in Political Science, UMCS. Research interests: international cultural relations, cultural diplomacy, human security, civil society in Latin America. 
Dossier América Latina: Venezuela movimiento migratorio sin precedentes. Partiendo de la hipótesis de que la intervención de la UE está en consonancia con sus aspiraciones de ser un actor global, la segunda parte del artículo analiza las medidas tanto políticas como financieras emprendidas por diversas instituciones europeas para ayudar a mitigar esta crisis humanitaria.

PALABRAS CLAVE: crisis migratoria, crisis política, régimen de Maduro, Unión Europea, Venezuela.

\section{Introduction}

Global economic, political, and technological transformations that have been taking place in recent decades have contributed to the increase of the flow of migrants all over the world. People who suffer because of political, economic, or social crises in their homeland desperately seek a safer place to live. Sometimes they fear for their lives, and sometimes they simply hope to have a better future for them and their children. Usually, in a time of a sudden or severe crisis, the neighboring countries take the most immediate impact of the flow of migrants who flee their country. However, in the long run, the refugees look for brighter future in wealthier - even if distant - parts of the globe. That is why mass migration or forced displacement may affect not only the regions where it takes place but must be regarded as a broader global concern.

In 2016, the United Nations Organization (UNO), addressing large movements of refugees and migrants, adopted a resolution "New York Declaration for Refugees and Migrants". The document indicated the scale of the phenomenon:

We are witnessing in today's world an unprecedented level of human mobility. More people than ever before live in a country other than the one in which they were born. Migrants are present in all countries in the world. Most of them move without incident. In 2015, their number surpassed 244 million, growing at a rate faster than the world's population. However, there are roughly 65 million forcibly displaced persons, including over 21 million refugees, 3 million asylum seekers and over 40 million internally displaced persons. (United Nations Organization, 2016, p. 2)

European Union is one of the most desired destinations for migrants and, from a political and economic point of view, it is thus vitally interested in diminishing the problems arising from mass migration movements. The year 2015, marked by an overflow of migrants trying to seek refuge in Europe, showed hard evidence of both deficiency of the European asylum system as well as coordination mechanisms at the national and EU levels, resulting in a chaotic response to the escalating problems.

As long as there is no solution or, at least, some consensus within international community on how to cope better with large migration movements, 
the problems will only escalate with time. It must be borne in mind that migration is a social phenomenon, and the impact of globalization is not limited to trade and information, but it also facilitates the transmission of social phenomena. Most likely the images of the mass migration from the Middle East to Europe, seen in the media and on social networks, gave the impulse to caravans of migrants who set out in October 2018 from Central America heading to the United States in search of better living conditions, driven by poverty and violence in their countries of origin. Their struggle to reach the "promised land" in the USA will also serve as an example for others who do not see any future in their countries and are desperate enough to face the challenges of migration. All this only augurs an increase in mass movements of population from poor and dangerous places to richer regions. Europe, considered one of such save havens, must both react and prepare adequately for current and future situations. This is particularly important in view of the aspirations of the European Union as one of the world political and economic leaders.

There is no doubt that the Latin American region and its problems related to mass migration movements is not a priority for the European Union, however, being an important actor of the international community, the EU is supposed to take a stand and show its capacity to participate actively in resolving conflicts in the world, whether it is in the form of political declarations, sanctions, etc., or the humanitarian and development aid and financial investments ${ }^{1}$. In the case of Venezuela, by using its voice and vote in international forums such as the United Nations, the EU is able to advocate for respect of human rights and a return to democracy.

The main purpose of the article is to analyze the response of the European Union to the political, economic, and humanitarian crisis in Venezuela, which has led to the mass exodus of migrants and refugees. The analysis will be carried out by presenting the causes, the effects, and the reaction of the EU to the phenomenon of mass migration from Venezuela. In the first part, a multidimensional background of the crisis will be outlined, then its scale and cross-border impact will be indicated. The second part of the article will be dedicated to presenting the measures undertaken by various European Union institutions in reaction to the political turmoil and humanitarian disaster in Venezuela which has led to the mass exodus from the country.

\section{Political crisis}

It is important to present the political background of the migration crisis because it is the main factor which contributed to the current situation in Vene-

\footnotetext{
1 See a short overview of relations between the European Union and Latin America in
} Oberda-Monkiewicz (2017).
The European Union's Reaction to the Venezuelan Migration Crisis

Maria Ochab 
Dossier América Latina: Venezuela zuela. The political factor is also relevant when analyzing the actions undertaken by the European Union towards the Maduro regime.

It is hard to believe that only ten years ago Venezuela was one of the richest countries in Latin America owing to the largest proved oil reserves in the world $^{2}$. It was able to provide help for thousands of Colombian refugees who fled their country because of a civil war ${ }^{3}$. Now the country's economic and political situation resembles a failed state rather than a prosperous country rich in natural resources.

This tragic situation is the result of years of populist rule of Chávez and Maduro regime. In order to increase his power, Chávez focused on two goals: dismantling democratic institutions that could control and put limits on his decisions, and seizing control over the economic sector of the country. $\mathrm{He}$ succeeded in both and gradually built an authoritarian, corrupt regime. His successor Maduro, who took power after Chávez's death, followed his steps during the first presidential term. However, in time, popular support for the regime started to dwindle. It was not possible to maintain social transfers on which the government initially had built its popularity. It turned out unfeasible to sustain country's economic growth depending on the unstable price of a single commodity, oil, while importing over $70 \%$ of other goods. The worsening living conditions of most of the population caused by hyperinflation, corruption, rampant crime, inefficiency of state institutions and public services led to popular protests and, in 2015, to the first victory of opposition in the parliamentary elections since the beginning of the Chavist regime and uninterrupted rule of Partido Socialista Unido Venezolano (PSUV). This victory was an impulse which started the course of events leading to the escalation of political conflict between the parliament (Asamblea Nacional - AN) and the government. Maduro ignored the decisions of AN and convened the National Constituent Assembly (Asamblea Nacional Constituyente - ANC).

The direct reason of the current political crisis were the controversies concerning the presidential elections of Maduro for the second term. The AN announced that the elections were fraudulent and - considering that the presidency had fallen vacant - the speaker of the AN Juan Guaidó declared himself acting president on 23 January 2019. Maduro ignored the decision of the AN. His supporters in the ANC elected a new parliament speaker Luis Parra. Guaidó was denied access to the parliament and started organizing massive

2 According to the BP Statistical Review of World Energy (June 2014) it amounted to 298.300 million barrels in 2013. However, Forbes points out that it may be overestimated as not all reserves can be technically or economically recoverable. What is more, the energy policy led by Chávez and his successor Maduro has not been focused on long term investment in the human resources and technical infrastructure of oil industry (Rapier, July 1, 2016).

3 Now, Colombia is returning that help. It is hosting around one million Venezuelans and, in spite of the strains their presence causes for the local communities, the Colombian government is trying hard to integrate them into the society, considering that placing them in refugee camps would be the last resource. 
protests as well as calling on the army to support him but the military in its majority decided to stay on Maduro's side.

The fact that Venezuela has two politicians claiming their right to presidency has divided the international community. Maduro can count on the support of Russia (accusing the United States of an attempt of illegal regime change), China (the largest foreign investor and creditor of Maduro regime), Cuba, Nicaragua, Bolivia, Turkey, Iran, Belarus, Syria. Mexico and Uruguay adopted a neutral position. The following countries recognized Guaidó as an interim president: US, Australia, Israel, the Lima Group members except for Mexico (including Argentina, Brazil, Chile, Colombia, Costa Rica, Guatemala, Honduras, Paraguay and Peru), some of the European countries (Austria, Britain, Croatia, the Czech Republic, Denmark, Estonia, Finland, France, Germany, Latvia, Lithuania, Luxembourg, the Netherlands, Portugal, Poland, Spain, Sweden) while other members of the EU call for new presidential elections in Venezuela (BBC News, February 5, 2019).

The continuing political turmoil has not been the only reason behind the mass migration of the Venezuelan citizens. The unstable political situation, resulting from the ineffective rule of the regime, was only one of the factors contributing to the growing discontent of the society. In the case of majority of migrants, the main reason for fleeing the country is the deepening economic crisis. The next chapter will give an outline of the current situation which, without any exaggeration, can be labelled as a deep humanitarian crisis, requiring the intervention of the international community in the form of humanitarian aid. That is why the European Union feels compelled to participate in various actions undertaken to mitigate this crisis.

\section{Economic crisis}

Main economic indicators reveal extremely bad condition of Venezuelan economy. According to the International Monetary Fund, the 2020 projected percentage change of real GDP would be at -15.0 (IMF, 2019), while the estimated inflation rate for 2020 would reach 500,000\% (World Bank, 2019). The most recent survey of living conditions (ENCOVI, 2020) reveals that $89 \%$ of population live in poverty and Venezuela has the second highest homicide rate among Latin American and the Caribbean countries (89 per 100,000 inhabitants). One of the major problems for families is unemployment and lack of financial resources. The breakout of pandemic has only aggravated the situation in the labor market. Job loss due to mobility restrictions because of Covid-19 increased by 6.9 percentage points nationwide and currently as much as $44 \%$ of the population age of 15 years and over is economically inactive.

Such economic crisis contributes to growing corruption and inefficiency of public services. According to the latest Transparency International report, $87 \%$ of Venezuelans believe that within 12 months analyzed in the survey co-
The European Union's Reaction to the Venezuelan Migration Crisis

Maria Ochab 
Dossier América Latina: Venezuela rruption increased and $50 \%$ of those who had to use public services had to pay bribes. They think that the most corrupt institution is president/prime minister $(87 \%)$. When asked "Is the government doing a good or bad job of fighting corruption?", 91\% of them answered "Bad" (Pring, Vrushi, 2019, p. 50). In the 2019 Corruption Perception Index, among 180 countries Venezuela occupies position 176 , with the score $16 / 100$ ( 0 is highly corrupt, 100 is very clean $)^{4}$, while the average score for the European countries is 66/100. Corruption undermines foundations of democracy as it is often used for illegal funding of political parties or buying votes during elections. In Venezuela, more than $20 \%$ of citizens were afraid of retaliation if they did not vote for the Maduro regime (Transparency International, 2019).

Additionally, the inefficient functioning of public services, such as water or electricity supply, have negative impact on health services, aggravating their already tragic state. According to a report Encuesta Nacional de Hospitales 19 (Organización Médicos por Salud y GIDETI, 2019) ${ }^{5}$, between November 2018 and December 2019 barely 9\% of hospitals had regular supplies of water, while $70 \%$ had it once or twice a week, and $20 \%$ reported not having it at all. Equally tragic is the situation with electricity supply. In 2019, 63\% of hospitals had intermittent supply of energy, and in March, during nationwide recurring blackouts, there was no electricity in hospitals for a total of 507 hours. The report attributes 26 deaths of hospital patients to ongoing power outages in that period and 164 during the whole year. Another problem registered in the report is the shortage of medical personnel, partly due to mass migration (the number of doctors decreased by $10 \%$ and nurses by $24 \%$ within a year). Because of all these problems there was also a decrease in the number of available operational infrastructure (the number of beds decreased by $44 \%$ while operating rooms were used only to $49 \%$ of their capacity). Such scarcity of services available was also the reason for increased levels of violence towards hospital personnel (662 incidents in 2019) and robberies or break-ins (490 cases reported).

Health and lives of Venezuelans are threatened not only by inefficient public services but also by shortages in food supplies. All of them being the consequence of collapsing economy and lack of financial resources. Only 3\% of households report not having any problems with food supply and 30\% of children under the age of 5 have symptoms of chronic malnutrition which will have irreversible impact on their future development (ENCOVI, 2020).

The general crisis has also affected the area of public education. Even though the number of school children has significantly decreased in Venezue-

\footnotetext{
4 Only in Yemen, Syria, South Sudan, and Somalia the level of corruption is even higher.

5 The report was prepared by Organización Médicos por Salud and GIDETI (group of Venezuelan scientists dedicated to researching tropical and infectious diseases), with the endorsement of the National Assembly, National Medical Academy, and other bodies. Its aim is to present to the public the detailed situation in the field of medical services based on surveys carried out in the major Venezuelan hospitals.
} 
la because of migration, the accessibility of education for poor families did not get any better. On the contrary, the risks of educational exclusion have increased among those who cannot maintain regular school attendance $(40 \%)^{6}$, and $13 \%$ of children aged 3-17 do not attend school at all (ENCOVI, 2020).

The deepening economic crisis leading to unprecedented hardships in everyday life (raging inflation and a continued shortage of basic food commodities, deficiency of health services, etc.), combined with political instability and lack of hope for positive changes, has led to an increasing desire of Venezuelans to leave their home country and initiated the phenomenon, which will be described in the following chapter.

\section{Migration crisis}

It is worth noting, that the phenomenon of migration is a general tendency in the region. However, while on average the number of citizens who would like to emigrate reaches approximately 27\% in Latin America, in Venezuela it amounts to 53\%, the highest level among all countries, comparable only with Dominican Republic ${ }^{7}$. It is a drastic change, comparing to the data from 2013, when only $12 \%$ Venezuelans wanted to emigrate (McCarthy, 2018). Venezuela is also the leader of the Potential Net Migration Index (PNMI), which shows the future growth of population in different countries according to forecasts based on migration movements in and out of the country. Venezuelan score dropped to -20 in the years 2013-16 (McCarthy, 2018). Of course, the fact that so many people would see the solution to their life problems in emigration does not mean that most of them might fulfil their dreams. But the fact is that approximately $13 \%$ of the whole population (over 4 million people) have left the country. In the recent years, the growth rate of emigration increased by 283.27\%. The principal destinations are Colombia (41.62\%), Peru (23.91\%), the United States (10.13\%), and in Europe, Spain with 6\% (Expansión, 2019).

The scale of the phenomenon of recent mass migration from Venezuela was evidenced in the recent National Survey of Living Conditions 2019-2020

6 The reasons for irregular school attendance are as follows: problems with water supply (23\%), blackouts (17\%), lack of food at home (16\%), transportation (7\%), lack of teachers (18\%) (ENCOVI, 2020).

7 According to the survey conducted by Latinobarómetro, in eighteen Latin American countries in 2018, approximately one third of the population would like to emigrate abroad. The data gathered by Latinobarómetro for 2018 showed that it was a year in which all economic, political and social indicators fell, some of which reached the most negative figures since the beginning of the measurements in 1995 (Latinobarómetro, 2018).

8 The more exact estimates of the number of emigrants are the following: $1.400 .000 \mathrm{Co}-$ lombia, 870.000 Peru, 385.000 Ecuador, 371.000 Chile, 351.000 United States, 224.000 Brazil, 145.000 Argentina, 94.000 Panama, 71.000 Mexico, 58.000 Spain, 30.000 Dominican Republic, 28.000 Costa Rica, 21.000 Trinidad and Tobago, 20.000 Canada, 17.000 Guyana, 16.000 Aruba, 16.000 Curaçao, 13.000 Uruguay, 5.000 Bolivia, 3.800 Paraguay (World Bank, 2019).
The European Union's Reaction to the Venezuelan Migration Crisis

Maria Ochab 
Dossier América Latina: Venezuela
(ENCOVI, 2020), according to which 19\% of households report that at least one of their members emigrated to another country in the 2014-2019 period. Moreover, half of the population that flees the country is young (aged between 15-20) and 23\% have a university degree. The fact that the country will lose young, educated population will be a huge problem both for the national demography and labor market. The main reason for emigration declared in the survey is the lack of employment and economic resources (82.8\%), while political reasons are mentioned by only $1.3 \%$. Before 2019 only $4 \%$ declared the will to return to the home country in the future and although the outbreak of the Covid-19 pandemic and subsequent lockdown made it more difficult to emigrate, it will not stop the exodus.

In addition to being confronted with a systematic disinformation on the part of the authorities, Venezuelan citizens suspiciously look at the measures the government undertakes in the face of the migration crisis. Some independent journalists maintain that the massive exodus comes in handy for the Maduro regime both from political and economic point of view. On the one hand, there is less political pressure as those who migrate often are opponents of the regime and that would explain the easing of barriers for getting passports. What is more, with the depopulation of the country by millions of citizens, there is lesser demand for public services. On the other hand, many Venezuelan families live off the remittances sent from abroad. It is estimated that for 2017 remittances reached around 2 billion dollars (Hermoso, 2018). In 2017 only 8\% of households received remittances, while in 2019-20 this number reached 30\% (ENCOVI, 2020).

\section{Impact on neighboring countries}

One of important observations concerning the Venezuelan migratory crisis is the fact that it is a part of a global phenomenon of the so-called "large movements". They differ from regular flow of migrants which happens constantly all over the world, and generally without incidents. According to UN Declaration for Refugees and Migrants (2016), large movements "may involve mixed flows of people, whether refugees or migrants, who move for different reasons but who use similar routes".

Such is the case of exodus from Venezuela where people leave the country not because of war, natural disaster, or ethnic cleansing. They leave the country being motivated by economic difficulties resulting from political crisis which have, in turn, led to a humanitarian disaster (further exacerbated by the Covid-19 pandemic). Besides all challenges that refugees and migrants usually face, they pose a serious problem for receiving neighboring or transit countries. Even though the international legal status of migrants and refugees is different, still equal human rights and fundamental freedoms apply to them. In case of Venezuelan migration crisis, it is Colombia and Peru that are mainly affected as host countries. Such a huge inflow of people seeking refuge has 
very deep repercussions in both economic and social sphere, particularly in employment, health, and education.

The MMC Research Report (2019) prepared by the Mixed Migration Center in collaboration with the Danish Refugee Council gives an overview of problems in the neighboring transit or host countries resulting from the exodus of Venezuelans. The key findings are as follows: 1) lack of financial resources exposes the migrants to all kinds of risks on the way out of the country, including crime, physical assault or sexual gender-based violence; 2) they face racism and discrimination as their growing number in host countries is provoking xenophobia; 3 ) to limit the influx of the increasing number of migrants, host countries start to impose stricter immigration rules; 4) not being able to comply with requirements of stricter immigration law, more and more Venezuelans try to enter the host countries illegally; 5) illegal movement across borders increases the demand of smuggling services and exposes migrants to higher risk of exploitation (MMC Research Report, 2019, p.7).

Although the migratory movements bring forth various negative consequences, it is worth noting some of their positive aspects as well. The positives are quite often ignored by citizens of host countries, who perceive immigrants as a threat to their economic stability, employment, safety, etc. In crisis situations, and such is the exodus of Venezuelans, xenophobia and prejudices spread easily, obscuring hard economic data.

One of the countries affected by Venezuelan migration is Peru, which must cope with approximately 870,000 immigrants. In 2019, the World Bank prepared a report indicating how immigrants contribute to Peruvian economy and what the Peruvian State should do to better use their potential. It is worth noting that they are mainly young ( $42 \%$ are between $18-29$ years of age), and what is more, $57 \%$ of working-age Venezuelans in Peru have higher education, and of these, half have a university degree. It is estimated that, in 2008, about $8 \%$ of Peruvian GDP growth was due to their contribution. The World Bank estimates that if the integration of Venezuelans into the local labor market becomes a reality, they could increase Peruvian productivity by $3.2 \%$. Even working in informal sector, they can generate tax revenue of about 2.25 billion soles (World Bank, 2019).

Nonetheless, the World Bank report seems to be more optimistic than the forecasts made by the International Monetary Fund, which foresees that the migration wave may reach up to 10 million people in 2023 . It would imply increase in public spending on humanitarian aid, healthcare, education, and other public services. IMF estimates that by 2023 this kind of expenditure could reach $0.6 \%$ of GDP in Colombia, $0.3 \%$ in Ecuador and Peru, and $0.1 \%$ in Chile (Corugedo, Guajardo, November 21, 2019). Even though Venezuelans could potentially raise GDP growth in the recipient countries by 0.1 to 0.3 percentage points during 2017-2030, in the short term they contribute to some difficulties in local labor markets by displacing domestic labor force and increasing informal employment (Corugedo, Guajardo, November 21, 2019).
The European Union's Reaction to the Venezuelan Migration Crisis

Maria Ochab 


\section{Dossier América Latina: Venezuela \\ The European Union's political reaction to the crisis in Venezuela}

The European Union, as a global player, takes a role of an advocate for human rights and democracy. That is why it took a stand in the case of the deepening crisis in Venezuela. Analyzing the steps undertaken by the EU, it is evident that the primary concern of the EU is to press Maduro regime to agree to fair elections and find a peaceful solution for the political conflict. The migration issue is regarded rather as a humanitarian disaster than a political issue (in fact, most of the Venezuelan migrants are not asylum-seekers).

One of the first reactions of the European Union to the political crisis resulting from the conflict between the Maduro's government and the parliamentary majority was the resolution adopted on July 18, 2016. The EU expressed interest in Venezuela gaining political stability. One of the reasons, apart from historical cultural ties with the country, was the fact that at that time over 600.000 Europeans resided there. In the conclusion, the Council of the EU urged the High Representative, the EEAS and the EU Commission to support mediation mission of the former presidents Mr. José Luis Rodríguez Zapatero, Mr. Leonel Fernández and Mr. Martín Torrijos, who acted under auspices of the Union for South American Nations, to help maintain dialogue between the government and the parliamentary majority in Venezuela (Council of the EU, July 18, 2016).

The following year, Venezuela was the subject of three conclusions and one decision on introducing targeted sanctions. In May, the EU again called for solution to the deepening crisis in Venezuela, indicating that the mediation had not brought any results up to that moment. However, apart from recalling, urging, expecting, and encouraging to resolve the growing problems, the EU did not take any firm action (Council of the EU, May 15, 2017). Next, there was a declaration by the High Representative Federica Mogherini (Council of the EU, July 26, 2017). It referred to the situation in Venezuela ahead of the election for the Constituent Assembly on 30 July 2017. Once again, after mentioning the escalating problems in Venezuela, there was a call for peaceful negotiations and responsibility of public authorities in view of infringement of fundamental rights of citizens.

Finally, in November, along with the conclusions (Council of the EU, November 13, 2017), the Council announced the decision to adopt restrictive measures voted by unanimity. The imposed measures included: 1) export restrictions concerning arms, equipment which could be used for internal repressions, or equipment, technology, and software intended for the monitoring of the internet and telephone communications by the Venezuelan regime; 2) restrictions on admission of natural persons responsible for serious human rights violations or whose actions undermine democracy or the rule of law in Venezuela; 3) freezing of funds and economic resources of natural or legal persons, entities or bodies responsible for serious human rights violations in Venezuela (Council of the European Union, November 14, 2017). 
Along with the deepening of the crisis in Venezuela, the political activity of the EU increased and, in 2018, eight declarations concerning Venezuela were made. After the presidential and regional elections which were held on 20 May, the EU criticized irregularities which occurred, such as lack of political pluralism and transparency, biased electoral conditions, obstacles to the participation of opposition political parties or an unbalanced composition of the National Electoral Council (Council of the European Union, May 22, 2018). On the next day, the EU reiterated the discontent with the electoral process through a joint declaration of the G-7 leaders, including Canada, France, Germany, Italy, Japan, the United Kingdom, the United States of America (European Council, May 23, 2018). The declaration included the call on the Venezuelan government to schedule new, fair elections.

In the following conclusions, adopted by the Council of the European Union on 28 May, there is finally a mention of the migration crisis:

The EU is deeply concerned about the pressing humanitarian needs of the population, including of many Europeans citizens residing in the country, which need to be addressed urgently. The worsening crisis is causing mass migration that creates challenges to host communities and to regional stability. The EU calls on the Venezuelan Government to take immediate action to alleviate the impact of the crisis. 10. The European Union will continue and step up its support to the population of Venezuela, also in neighboring countries, supporting the socio-economic inclusion of Venezuelans and resilience of host communities. (Council of the European Union, May 28, 2018)

The next step was taken by the EU on 25 June, with the decision on the amendment of the list of 7 Venezuelan officials on sanction lists by 11 more representants of the Maduro regime (Council of the European Union, June $25,2018)$.

On 15 October, another EU body discussed the Venezuelan crisis. It was the Foreign Affairs Council. The High Representative and foreign ministers discussed the idea of establishing a contact group to help carry out the political solution of the Venezuelan crisis. They also discussed the impact of Venezuelan migration in the neighboring countries; however, the discussion on external aspects of migrations was mainly focused on Libya and the strategic partnership between the EU, the IOM and the UNHCR in Libya (European Council, October 15, 2018).

Very soon, further concern of the EU for the situation in Venezuela was expressed. The High Representative Federica Mogherini once again mentioned the issue of migration in the declaration pronounced on 25 October 2018:

The EU and its Member States will step up their support to national, regional and multilateral efforts aimed at mitigating the effects of the migrant crisis, as well as addressing the most urgent needs of the population inside
The European Union's Reaction to the Venezuelan Migration Crisis

Maria Ochab 
Dossier América Latina: Venezuela the country. Countries in the region and their citizens should be supported in this challenging situation. This regional crisis requires regional and global concerted responses. In this respect, the EU welcomes the appointment of $M r$. Eduardo Stein as Joint Special Representative of UNHCR and IOM for Venezuelan refugees and migrants. The EU calls on the Venezuelan government to take concrete action to alleviate the impact of the crisis, including the facilitation of external cooperation to address the most urgent needs of the population. (Council of the European Union, October 25, 2018)

The next step undertaken by the EU to exert pressure on the Maduro regime was to renew for another year the embargo on arms and the sanctions imposed on 18 Venezuelan officials (Council of the European Union, November 6, 2018).

In the beginning of 2019, apart from declarations expressing disagreement and discontent with the fact that Maduro decided to inaugurate his presidential mandate and later violently responded to popular protests, the EU decided to take part in establishing an international contact group on Venezuela. Its purpose was the following:

... promote a common understanding and a more concerted approach among key international actors on the situation in Venezuela aiming at a peaceful and democratic solution to the current crisis. The group will help to build trust and create the necessary conditions for a credible process to emerge, in line with the relevant provisions of the Venezuelan Constitution, enabling Venezuelans to determine their own future, through the holding of new elections with all guarantees for a free and fair electoral process, supervised by international independent observers. The objective is not to be a mediator but to support a political dynamic that the group can then further accompany and consolidate. (Council of the European Union, January 31, 2019)

The main purpose of the International Contact Group (ICG) was to convince Maduro to organize new elections within 90 days. The inaugural meeting of the ICG took place during the conference co-hosted by Uruguay and the EU in Montevideo on 7 February 2019. The group included the EU, eight of its Member States (France, Germany, Italy, the Netherlands, Panama, Portugal, Spain, Sweden), the United Kingdom, Bolivia, Costa Rica, Ecuador, Mexico, and Ecuador. Maduro welcomed this initiative of talks with opposition, but Guaidó accused Maduro of using this to prolong and strengthen his regime and refused to enter the dialogue with him (Aguilar Ybarra, February 4, 2019). The ICG did not achieve its goal as Maduro ignored its 90-days deadline for organizing new elections.

Within 2019 and 2020 there were various declarations, in which the EU reiterated its support to the political solution of the crisis as well as its readiness to increase humanitarian and development aid, condemned the Maduro regime for not letting in humanitarian aid from abroad, expressed concern 
about personal freedom and safety of Juan Guaidó, condemned the fact that the German ambassador in Venezuela was pressed to leave the country, called for releasing political prisoners, extended the sanctions to more regime officials, etc. The sanctions against 11 high officials announced on 29 June 2020 almost caused the disruption of diplomatic ties between the EU and Venezuela. The reaction of the Maduro government after the EU announced the sanctions was to declare Isabel Brilhante Pedrosa, Head of the Delegation of the European Union in Caracas, a persona non grata and demand that the EU Ambassador leave Venezuela within 72 hours. The EU condemned the decision and announced that it would keep on supporting Venezuelan citizens in their strive for democracy and would continue the humanitarian assistance (European Council, 2020). However, on 2 July, after the phone conversation between Josep Borrell, the European Union's High Representative for Foreign Affairs and Security Policy, and Jorge Arreaza, the Venezuelan Minister of People's Power for Foreign Affairs, the Venezuelan government revoked that decision and agreed on the need to maintain diplomatic relations at the highest level in order to facilitate political dialogue and cooperation (EEAS, 2020).

It is worth noting that various international bodies made efforts to contribute to the resolution of the Venezuelan crisis. One of them is the Organization of American States (OAS), which brings together 35 Latin American countries as well as 69 permanent observers (one of them is the European Union) and is considered as an important forum of political dialogue in the Western Hemisphere. The OAS took various steps to find political solution for the problem and published reports denouncing the deterioration of the rule of law and democratic institutions in Venezuela. Unfortunately, none of its initiatives received enough support from its members to have a major political impact ${ }^{9}$. Nonetheless, at least the OAS managed to attract attention of the international community to the multidimensional crisis in Venezuela by presenting it in the International Criminal Court (Krzywicka, 2019).

The reaction of the EU to the deepening crisis in Venezuela was not limited to the above-mentioned political declarations and sanctions. Other measures were taken to help Venezuelan citizens who decided to flee the country submerged in a total chaos on the verge of collapse. These measures will be described in the next chapter.

\section{The European Union's humanitarian help for Venezuelan migrants}

Since 2016, when the political and economic crisis in Venezuela became more acute, various EU bodies have been taking steps in reaction to the developments in Venezuela as well as participating in actions undertaken by different

9 More detailed account of the OAS actions can be found in K. Krzywicka (2019).
The European Union's Reaction to the Venezuelan Migration Crisis

Maria Ochab 
Dossier América Latina: Venezuela international entities. The political reaction of the EU has been described in the previous chapter and this one will focus on humanitarian aid provided for Venezuelan migrants.

The analysis of the Political Guidelines for the Next European Commission 2019-2024, prepared by Ursula von der Leyen (Von der Leyen, 2019), reveals that the problem of migration has its place among the priorities of the European Commission, however, it is perceived rather from a perspective of events which took place in Europe and neighboring countries and which unsettled the sense of security of many Europeans. It is enclosed in the words "Protecting our European way of life". The proposals for action comprise the following: strengthening the external borders, modernizing the Common European Asylum System (with the emphasis on being common, as recent years showed that not all Member States agree on common policy in this area), improving internal security by having better instruments to fight against transnational crime and terrorism, reinforcing customs control to better protect the European single market. Although the document reaffirms the need to provide aid and development cooperation to the countries of origin of the immigrants, the only region that is mentioned is Africa, the region which has the most direct impact on the EU in the context of migration and security.

The document also reveals one of the major weaknesses of the EU - its decision-making process. To improve it, Ursula von der Leyen proposed to replace the unanimity voting by majority voting. She also suggested more coordinated external actions, particularly in development aid and security policy. But then again, the focus is on neighboring countries as most immigrants, in particular illegal ones, come from them.

When analyzing the annual 2020 EU budget, it is also evident that, at present, the Venezuelan crisis is not a priority for Europe. The budget had to be urgently amended to provide more financial resources in the area of particular importance: the Covid-19 crisis, which is the mayor challenge Europe is facing currently (Council of Europe, 2020). In fact, the budget was amended various times within 2020, and some of the amendments were addressing the problem of migration, however, the focus was on Syrian refugees and the humanitarian help for them and host or transit countries such as Turkey, Jordan, Lebanon, and Greece.

Nonetheless, the European Union is not ignoring the Venezuelan migration crisis. It is worth noting that, in 2019, for the first time since the peak of migration crisis in Europe, which took place in 2015, there was a rise in applications for asylum. What is more, in 2019, Spain received more asylum applications than during the 2015 , and it was due to about 46.000 Venezuelan citizens who applied for asylum ${ }^{10}$. Their applications got much higher rate of

${ }^{10}$ One of the reasons why Venezuelans choose Europe as a destination is the fact that for the time being (until 2022, when the European Travel Information and Authorization System ETIAS will be launched) they do not need visa to enter the Schengen Area. 
approval, reaching the level of $96 \%$ in 2019, as compared to $29 \%$ in 2018 (EASO, 2020).

The European Union offers humanitarian help mainly through a specialized body - the European Commission Civil Protection and Humanitarian Aid Operations (ECHO) department. It has been active since 1992 and has an annual budget of approximately $€ 1$ billion. The legal basis for its activity is set up in the article 214 of the Lisbon Treaty:

1. The Union's operations in the field of humanitarian aid shall be conducted within the framework of the principles and objectives of the external action of the Union. Such operations shall be intended to provide ad hoc assistance and relief and protection for people in third countries who are victims of natural or man-made disasters, in order to meet the humanitarian needs resulting from these different situations. The Union's measures and those of the Member States shall complement and reinforce each other.

2. Humanitarian aid operations shall be conducted in compliance with the principles of international law and with the principles of impartiality, neutrality and non-discrimination. (Treaty of Lisbon, 2007)

In the case of the humanitarian crisis in Venezuela, since 2018 the EU donated $€ 156$ million. The funds were allocated both for projects inside the country and for neighboring countries which have been hosting Venezuelan migrants. Help was provided in the area of healthcare, water, sanitation, education, protection, food. The EU also included help for Venezuela within the frames of its Coronavirus Global Response. It organized Humanitarian Air Bridge, delivering 82.5 tons of life-saving material. The operation was carried out jointly by the EU, Spain, Portugal, in coordination with the authorities of Venezuela (ECHO, n.d.). Also, the ECHO contributed $€ 3.2$ million to the activities of UNICEF aimed at bringing relief to migrant children and host families in Brazil, Colombia, Ecuador, Trinidad and Tobago (UNICEF, 2020). Another example of aid is the project "Cities of Solidarity" ( $€ 16$ million), aimed at helping local administration in cities which receive migrants and refugees to integrate them socially and economically into the local community. The EU also donated $€ 9$ million to support the Pan-American Health Organization in combating Covid-19 (EEAS, May 26, 2020a).

In order to raise awareness about the tragic situation of the Venezuelan migrants and mobilize funds for their urgent needs, the EU organized the International Solidarity Conference on the Venezuelan Refugee and Migrant Crisis, which took place in Brussels on 28-29 October 2019. The conference was organized by the EU, UN Refugee Agency (UNHCR), and the International Organization for Migration (IOM). The participants included various EU institutions, representatives of Member States and affected Latin American and Caribbean countries, donors, UN agencies, private sector, NGOs, as well as international financial institutions. Federica Mogherini, who co-chaired the conference, said:
The European Union's Reaction to the Venezuelan Migration Crisis

Maria Ochab 
Dossier América Latina: Venezuela

This is a moment to call for even greater support for Venezuelan refugees, migrants and their host communities by the international community. We want to raise awareness about the gravity of this crisis, we want to confirm and increase international support for a regional and coordinated response. The EU is already the leading donor and key political player, providing $€ 170$ million since 2018 in support of the Venezuelan people. (UNHCR, 2019)

That conference was not a pledging one, but it was followed by another event, this time virtual, aimed at collecting funds for Venezuela. The Donors Conference in Solidarity with Venezuelan Refugees and Migrants in Countries in the Region, Amid the COVID-19 Pandemic, was held on 26 May 2020. It was organized by the EU, together with the Spanish government and with support of the UNHCR, the IOM, Norway and Canada. It raised $€ 3.1$ billion from over 60 countries and institutions. The European Union's contribution reached $€ 144$ million (including $€ 50$ million from Spain), while the European Investment Bank offered $€ 400$ million in loans (EEAS, May 26, 2020b).

As it was mentioned before, the humanitarian aid from the part of the EU is channeled in various ways and in cooperation with different international organizations. One of the examples is the Red Cross EU Office, which comprises 27 National Red Cross Societies from all EU Member States along with the Norwegian Red Cross, the British Red Cross, and the International Federation of Red Cross and Red Crescent Societies. Since 2018, it has been providing help for the Venezuelans on the move in the bordering countries (Colombia, Peru, Ecuador). The project focuses on health assistance and facilitation of communication between migrants and their families. The partners in this project are German and Spanish Red Cross, the European Commission's Directorate-General for European Civil Protection and Humanitarian Aid Operations as well as Colombian, Peruvian and Ecuadorian Red Cross (Red Cross EU Office, n. d.).

Apart from providing help in emergency situations, the European Union is also the biggest donor of the development assistance in the world.

When analyzing the budget of donors and recipient countries, it is visible that member states focus their interests on particular recipient countries. In case of Venezuela, the biggest donor is Spain, the country with the closest historical, cultural and economic bonds with Venezuela. Its disbursement reached $€ 146.45$ million of the total sum of development assistance donated to Venezuela in the years 2007-2020, which amounted to $€ 442.57$ million (EU Aid Explorer, n.d.).

The above-mentioned financial resources are not the only form of help provided by the EU to Venezuela in its critical situation. There is a range of other European entities, NGOs, organizations, etc., which have been sending humanitarian aid to Venezuela and the host countries for the Venezuelan migrants and refugees. The European Union provides humanitarian aid within its budget funds, but we must not forget that also Member States, on their own, organize or take part in actions of humanitarian or development help. 
There is no doubt that Venezuela is not a priority, especially nowadays, during the economic problems caused by the pandemic even in wealthy countries, however the European Union is not withdrawing from the international arena.
The European Union's Reaction to the Venezuelan Migration Crisis

Maria Ochab

\section{Conclusions}

It is unquestionable that the European Union is trying to play an active role in world politics and, as one of the wealthiest and safest regions, it is willing to take some responsibilities in view of crisis situations in different parts of the globe. Of course, closer the problems are to the European borders, the more willing Member States are to act. Obviously, the Venezuelan migration crisis does not have such a direct impact on the EU as do the migration waves coming from across the EU borders. This is the reason why the reaction of the EU bodies, particularly in its political dimension, may seem rather cautious and not very swift, based mainly on reiterative declarations and statements. It seems that the EU, having in mind the colonial past of some of its members, does not want to be perceived as an entity which imposes political solutions concerning internal matters of other countries. However, the EU actively participates in providing humanitarian aid to the Venezuelan migrants and cooperates with other organizations to this end. Unfortunately, despite reluctantly accepting some humanitarian aid, the Maduro regime does not respect any declarations or calls pronounced by the EU. Even the imposed sanctions do not change his stand. In a way, it shows the weakness and ineffectiveness of the measures that are at the disposal of the EU and the whole international community. Nonetheless, the direct humanitarian aid provided by the European institutions and Member States is priceless for the people fleeing the totally collapsed country.

Apart from taking action in face of critical situations, such as the case of Venezuela, the international community should start thinking of the migration in more general terms, having in mind the rising scale of this phenomenon. It should reconsider the legal status and approach towards migrants as quite often their factual situation does not fit the categories ascribed to people who flee their country. For example, Venezuelan migrants, who in their majority do not have the refugee status, can be labelled as "survival migrants", as their exodus is motivated by an extremely difficult economic situation which is, in turn, caused by poor governance and political crisis rather than political persecution per se. On the other hand, it cannot be denied that they are fleeing "massive violations of human rights or other circumstances which have seriously disturbed public order", thus complying with the definition of refugees adopted in the 1984 Cartagena Declaration (UNHCR, 1984). The legal status of migrants is very important with regard to their rights in the host countries and the responsibility of the international community to protect them and offer humanitarian aid. What is more, humanitarian aid providing temporary 
Dossier América Latina: Venezuela relief at the borders in situations of acute crisis provoked by mass influx of people is not enough in the long run. The development-based approach to displacement is necessary, aimed at the socio-economic inclusion of displaced populations rather than their encampment in refugee camps established in the host countries. This approach is much more beneficiary for all stakeholders involved.

Summing up the analysis of the European Union's actions in the face of the Venezuelan migratory crisis, I would like to bring up two quotes by Josep Borrell, the present High Representative of the Union for Foreign Affairs and Security Policy. He was appointed to hold this position on 1 December 2019 and migratory issues as well as many other problems that beset the world have been constantly present on his agenda, especially now, when all the political and economic problems are being augmented by the Covid-19 pandemic. He said: "We cannot change big global trends, but we can change how we respond to them." This is his vision of the role of Europe, as a "partner of choice" for other countries or regions. However, he realizes the weaknesses of the European decision-making process:

By investing more in unity, all Member States would gain in influence, because by slowing things down or weakening our capacity to act, they also harm themselves. In the EU, what matters is not how a discussion begins, with a range of views among 27 countries, each with their own histories and different interests. What matters is how a discussion ends, with a common vision on what to do and a commitment to put resources behind it. (Borrell, 2020)

This is a constant point of contention when it comes to political or financial engagement of the EU in the world. On the one hand, there are interests of particular Member States, and on the other, a broader vision of Europe's role as one of the world leaders, which comes with a cost. Considering all the challenges that both the European Union and Europe as a continent face currently, it doesn not seem probable that Venezuela, or Latin American region would at some point gain more importance in the European agenda. Nonetheless, any kind of help, whether in the form of financial resources or humanitarian assistance, is absolutely essential and more than welcomed by the Venezuelan citizens in their tragic situation. The political issues and implications on the relations with the Venezuelan government should not be placed before the moral obligation to follow the ideals on which the European Union was founded. The challenge that Europe keeps on facing was expressed in the European Agenda on Migration:

We need to restore confidence in our ability to bring together European and national efforts to address migration, to meet our international and ethical obligations and to work together in an effective way, in accordance with the principles of solidarity and shared responsibility. (European Commission, 2015) 
The key word when it comes to the European Union's efforts to mitigate negative impact of mass migration movements both within the EU and in Latin America is cooperation. It must be a multilateral cooperation within the entire international community so that the solutions bring benefits not only to the population seeking help but to their host countries and other stakeholders involved as well. Individual country actions aiming at defending strictly national interests, such as for example border restrictions, will not solve the problem of mass movement of migrants.

\section{Bibliographic references}

Aguilar Ybarra, R. (February 4, 2019). ¡Únanse a nuestro llamado democrático!, pide Guaidó. Impulso. Retrieved June 23, 2020, from https://impulsoedomex.com.mx/unansea-nuestro-llamado-democratico-pide-guaido/

BBC News (February 5, 2019). Maduro and Guaidó: Who is supporting whom in Venezuela? Retrieved June 23, 2020, from https://www.bbc.com/news/world-latin-america-47053701

Borrell, J. (2020). The rentrée of 2020: decision time for EU foreign policy. European Union External Action. Retrieved August 27, 2010, from https://eeas.europa.eu/headquarters/ headquarters-homepage/84439/node/84439_en

BP Statistical Review of World Energy (June 2014). Retrieved June 23, 2020, from https:// web.archive.org/web/20150609095748/https://www.bp.com/content/dam/bp/pdf/Energyeconomics/statistical-review-2014/BP-statistical-review-of-world-energy-2014-full-report.pdf

Corugedo, E. F. y Guajardo, J. (November 21, 2019). For Venezuela’s Neighbors, Mass Migration Brings Economic Costs and Benefits. Retrieved June 23, 2020, from https:// blogs.imf.org/2019/11/21/for-venezuelas-neighbors-mass-migration-brings-economiccosts-and-benefits/

Council of the European Union (July 18, 2016). Council conclusions on Venezuela. Press release. Retrieved June 23, 2020, from https://www.consilium.europa.eu/en/press/pressreleases/2016/07/18/fac-venuela-conclusions/

Council of the European Union (May 15, 2017). Council conclusions on Venezuela. Press release. Retrieved June 23, 2020, from https://www.consilium.europa.eu/en/press/pressreleases/2017/05/15/fac-venezuela-conclusions/

Council of the European Union (July 26, 2017). Declaration by the High Representative on behalf of the European Union on the situation in Venezuela. Press release. Retrieved June 23, 2020, from https://www.consilium.europa.eu/en/press/press-releases/2017/07/26/ hrvp-declaration-situation-venezuela/

Council of the European Union (November 13, 2017). Venezuela: EU adopts conclusions and targeted sanctions. Press release. Retrieved June 23, 2020, from https://www.consilium. europa.eu/en/press/press-releases/2017/11/13/venezuela-eu-adopts-conclusions-andtargeted-sanctions/

Council of the European Union (November 14, 2017). Council Decision (CFSP) 2017/2074 of 13 November 2017 concerning restrictive measures in view of the situation in Venezuela. Official Journal of the European Union L 295/60. Retrieved June 23, 2020, from https://eur-lex.europa.eu/ legal-content/en/TXT/?uri=uriserv:OJ.L_.2017.295.01.0060.01.ENG\&toc=OJ:L:2017:295:TOC
The European Union's Reaction to the Venezuelan Migration Crisis

Maria Ochab 
Dossier América Latina: Venezuela
Council of the European Union (May 22, 2018). Declaration by the High Representative on behalf of the EU on the presidential and regional elections in Venezuela. Press release. Retrieved June 23, 2020, from https://www.consilium.europa.eu/en/press/pressreleases/2018/05/22/declaration-by-the-high-representative-on-behalf-of-the-eu-on-thepresidential-and-regional-elections-in-venezuela/

Council of the European Union (May 28, 2018). Venezuela: Council adopts conclusions. Press release. Retrieved June 23, 2020, from https://www.consilium.europa.eu/en/press/ press-releases/2018/05/28/venezuela-council-adopts-conclusions/

Council of the European Union (June 25, 2018). Council decision (CFSP) 2018/901 of 25 June 2018 amending Decision (CFSP) 2017/2074 concerning restrictive measures in view of the situation in Venezuela. Official Journal of the European Union L 160 I/12. Retrieved June 23, 2020, from https://eur-lex.europa.eu/legal-content/en/TXT/PDF/?uri=CELEX:32018D0901\&f rom $=\mathrm{EN}$

Council of the European Union (January 31, 2019). International Contact Group on Venezuela - Terms of Reference. RELEX.1.A, 5958/19. Retrieved June 23, 2020, from https://www.consilium.europa.eu/media/38043/st05958-en19-icg-terms-of-reference.pdf

Council of the European Union (April 14, 2020). Tackling COVID-19: Council adopts amended EU budget for 2020. Press release. Retrieved June 23, 2020, from https://www. consilium.europa.eu/en/press/press-releases/2020/04/14/tackling-covid-19-counciladopts-amended-eu-budget-for-2020/

Council of the European Union (October 25, 2018). Declaration by the High Representative on behalf of the EU on the situation in Venezuela. Press release. Retrieved June 23, 2020, from https://www.consilium.europa.eu/en/press/press-releases/2018/10/25/declaration-bythe-high-representative-on-behalf-of-the-eu-on-the-situation-in-venezuela/

Council of the European Union (November 6, 2018). Venezuela: EU renews sanctions for one year. Press release. Retrieved June 23, 2020, from https://www.consilium.europa.eu/en/ press/press-releases/2018/11/06/venezuela-eu-renews-sanctions-for-one-year/

ENCOVI (2020). Encuesta Nacional de Condiciones de Vida 2019-2020. Instituto de Investigaciones Económicas y Sociales. Retrieved June 23, 2020, from https://www. proyectoencovi.com/informe-interactivo-2019

EU Aid Explorer (n.d.). Recipients. European Commission. Retrieved July 5, 2020, from https://euaidexplorer.ec.europa.eu/content/explore/recipients_en

European Asylum Support Office (EASO). (2020). EASO Asylum Report 2020: Annual Report of the Situation of Asylum in the European Union. Retrieved July 23, 2020, from https://easo.europa.eu/asylum-report-2020

European Civil Protection and Humanitarian Aid Operations (ECHO). (n.d.). Retrieved July 5, 2020, from https://ec.europa.eu/echo/where/latin-america-caribbean/venezuela_en

European Commission (2015). European Agenda on Migration. Brussels. Retrieved June 20, 2020, from https://eur-lex.europa.eu/legal-content/EN/TXT/?qid=1485255362454\&ur $\mathrm{i}=$ CELEX:52015DC0240

European Council(May 23,2018). G7 Leaders' Statement on Venezuela. Press release. Retrieved June 20, 2020, from https://www.consilium.europa.eu/en/press/press-releases/2018/05/23/ g7-leaders-statement-on-venezuela/

European Council (October 15, 2018). Foreign Affairs Council, 15 October 2018. Main results. Press release. Retrieved July 5, 2020, from https://www.consilium.europa.eu/en/ meetings/fac/2018/10/15/ 
European Council (2020). Declaration by the High Representative, on behalf of the European Union, on the latest developments in Venezuela. Press release. Retrieved July 5, 2020, from https://www.consilium.europa.eu/en/press/press-releases/2020/06/30/venezueladeclaration-by-the-high-representative-on-behalf-of-the-european-union-on-the-latestdevelopments-in-venezuela/

European External Action Service (EEAS) (2020). Joint communiqué after the phone call between High Representative Borrell and Minister Arreaza. Brussels. Retrieved July 5, 2020, from https://eeas.europa.eu/delegations/venezuela/81964/venezuela-jointcommuniqu \%C3\%A9-after-phone-call-between-high-representative-borrell-andminister_en

European External Action Service (EEAS). (May 26, 2020a). Factsheet on EU support to Venezuelan refugees, migrants and host communities. Retrieved June 20, 2020, from https://eeas.europa.eu/headquarters/headquarters-homepage/69487/node/69487_en

European External Action Service (EEAS). (May 26, 2020b). International Donors Conference in solidarity with Venezuelan Refugees and Migrants - \#Together4Venezuelans. Retrieved June 20, 2020, from https://eeas.europa.eu/headquarters/headquarters-homepage/79328/donorsconference-solidarity-venezuelan-refugees-and-migrants-countries-region-amid-covid-19_en

Expansión (s.f). Los venezolanos emigran más. Retrieved June 22, 2020, from https:// datosmacro.expansion.com/demografia/migracion/emigracion/venezuela

Gallup (2017). Potential Net Migration Index Falls in Middle East, Latin America. Retrieved June 22, 2020, from https://news.gallup.com/poll/212141/potential-net-migration-fallsmiddle-east-latin-america.aspx

Hermoso, C. (March 13, 2018). La estrategia del exilio. Efecto Cocuyo. Retrieved June 22, 2020, from https://web.archive.org/web/20180329211945/http:/efectococuyo.com/opinion/ la-estrategia-del-exilio

IMF (2019). Venezuela. Country Data. Retrieved June 26, 2020, from https://www.imf.org/ en/Countries/VEN\#countrydata

Krzywicka, K. (2019). La Organización de Estados Americanos frente a la crisis del Estado en Venezuela. Revista del CESLA. International Latin American Studies Review, no. 23, pp. 383-398. Retrieved June 26, 2020, from https://www.revistadelcesla.com/index.php/ revistadelcesla/article/view/532/463

Latinobarómetro (2018). Informe 2018. Santiago de Chile: Corporación Latinobarómetro. Retrieved June 22, 2020, from https://www.latinobarometro.org/lat.jsp

McCarthy, J. (March 6, 2018). Four in 10 Venezuelans Would Leave Venezuela Behind. Gallup News. Retrieved June 22, 2020, from https://news.gallup.com/poll/228338/fourvenezuelans-leave-venezuela-behind.aspx

MMC (2019). Waning welcome: the growing challenges facing mixed migration flows from Venezuela. A field assessment study in Colombia and Peru. Mixed Migration Center. Retrieved June 26, 2020, from: http://www.mixedmigration.org

Oberda-Monkiewicz, A. (2017). Evolution of EU-Mexico: time for real partnership?. Anuario Latinoamericano - Ciencias Políticas y Relaciones Internacionales, vol. 4, pp. 187-202. Retrieved June 19, 2020, from: https://journals.umcs.pl/al/article/view/5432 DOI: http://dx.doi.org/10.17951/al.2017.4.187

Organización Médicos por Salud y GIDETI (2019). Encuesta Nacional de Hospitales. Retrieved June 23, 2020, from: https://2479be6a-2e67-48df-9858-103ea763ef46.filesusr. com/ugd/0f3ae5_6bf4b730d6ab43589a30c303dd01880b.pdf
The European Union's Reaction to the Venezuelan Migration Crisis

Maria Ochab 
Dossier América Latina: Venezuela
Pring, C. \& Vrushi, J. (2019). Citizens' Views and Experiences of Corruption. Global Corruption Barometer. Latin America \& The Caribbean 2019. Transparency International. Retrieved June 23, 2020, from https://images.transparencycdn.org/images/2019_GCB_ LatinAmerica_Caribbean_Full_Report_200409_091428.pdf

Rapier, R. (July 1, 2016). Venezuela's Oil Reserves Are Probably Vastly Overstated. Forbes. Retrieved June 23, 2020, from https://www.forbes.com/sites/rrapier/2016/07/01/ venezuelas-oil-reserves-are-probably-vastly-overstated/\#43025130612c

Red Cross EU Office (n. d.). Activities. Assisting Venezuelans on the move. Retrieved June 19, 2020, from https://redcross.eu/projects/assisting-venezuelans-on-the-move

Transparency International (2019). Corruption Perceptions Index. Retrieved June 26, 2020, from https://www.transparency.org/en/news/cpi-2019-global-highlights

Treaty of Lisbon (December 17, 2007). Treaty of Lisbon Amending the Treaty on European Union and the Treaty Establishing the European Community. Official Journal of the European Union, (2007/C 306/01). Retrieved June 25, 2020, from https://eur-lex.europa. eu/legal-content/EN/TXT/?uri=celex\%3A12007L\%2FTXT

UNHCR (1984). Cartagena Declaration on Refugees, Colloquium on the International Protection of Refugees in Central America, Mexico and Panama, 22 November 1984. Retrieved June 19, 2020, from https://www.refworld.org/docid/3ae6b36ec.html

UNHCR (2019). Solidarity conference calls for action as Venezuelans depart in droves. Joint Press Release by the European Union, UNHCR and IOM. 23 October 2019. Retrieved June 19, 2020, from https://www.unhcr.org/news/press/2019/10/5db00d364/solidarityconference-calls-action-venezuelans-depart-droves.html

UNICEF (2020). EU humanitarian aid contributes $€ 3.2$ million to support UNICEF's humanitarian response for children affected by the Venezuelan migration crisis. Press release. Retrieved August 3, 2020, from https://www.unicef.org/lac/en/press-releases/euhumanitarian-aid-support-unicef-humanitarian-response

United Nations (2016). New York Declaration for Refugees and Migrants. Draft resolution referred to the high-level plenary meeting on addressing large movements of refugees and migrants by the General Assembly at its seventieth session. New York. Retrieved June 19, 2020, from https://www.un.org/ga/search/view_doc.asp?symbol=A/71/L.1

Von der Leyen, U. (2019). A Union that strives for more. My agenda for Europe. Brussels. Retrieved July 5, 2020, from https://ec.europa.eu/info/sites/info/files/political-guidelinesnext-commission_en_0.pdf

World Bank (2019). Venezuelan Migration: The 4,500-Kilometer Gap Between Desperation and Opportunity. Retrieved June 23, 2020, from https://www.worldbank.org/en/news/ feature/2019/11/26/migracion-venezolana-4500-kilometros-entre-el-abandono-y-laoportunidad 